Article

\title{
Education on Old Age and Ageing in School: An Analysis of Students' Conceptions of Old Age and Ageing and Implications for Teaching
}

\author{
Franziska Ginschel * and Kirsten Schlüter(D) \\ Institute of Biology Education, University of Cologne, D-50931 Cologne, Germany; \\ kirsten.schlueter@uni-koeln.de \\ * Correspondence: franziska.ginschel@uni-koeln.de
}

Received: 7 August 2020; Accepted: 27 October 2020; Published: 29 October 2020

\begin{abstract}
Issues related to old age and ageing are an imperative topic in a society of long life, concerning everyone. Wherever possible, the age-related issues should also be adequately addressed and integrated into school education. This article gives an overview of perceptions of students in regard to external and self-images of old age, as conceptions from students are an important starting point for the development of teaching approaches. So far, there is an insufficient research situation in Germany regrading images of old age of children and adolescents. Guideline-supported individual interviews with 10 ninth graders $\left(M_{\text {age }}=15.2\right.$ years $)$ were conducted and analyzed in order to get an insight into prevalent conceptions of old age and ageing in this age cohort. The students' ideas result in a comprehensive category system. In summary, our investigation has shown that students do not hold one-sided positive or negative images of old age in general, although some aspects like the physical condition and exercise capacity are seen more negatively than for example the characteristics of older persons. Teaching approaches for biology lessons and other subjects, deducted from the students' perceptions, are given in the discussion.
\end{abstract}

Keywords: biology education research; qualitative research; students' conception; old age

\section{Introduction}

Demographic change is leading to fundamental social changes in the age structure worldwide, which have an impact on the entire population [1]. Major demographic trends in Germany are demographic ageing and a declining population [2,3]. According to forecasts, the proportion of over 67-year-olds will continue to rise sharply over the next two decades [4]. In a society of long life, old age and the ageing process are becoming ever more important issues that persons of all age groups need to be prepared for [5,6]. The terms "old age" and "ageing" are directly linked. However, we have to distinguish carefully between them. The term "old age" refers to a state, i.e., the result of growing old. Older persons as a part of society and their stage of life are at the focus of attention. The meaning of the term "ageing", on the other hand, lies in the processes and procedures that lead to becoming old [7]. Old age has to be considered from a multidimensional perspective, since calendrical, biological, social, psychical, and functional age are facets of this concept [8]. Ageing processes are diverse, they are influenced by different dimensions of persons' individual lives, and their living situations. The financial situation, living environment, network resources, and the state of health differ from person to person, therefore ageing is a highly individual process [9]. It is apparent that ageing entails complex changes on a physiological, social, and psychological level. Healthy ageing, as a lifespan concept, can improve the individual ageing process [10]. Health, according to the World Health Organization (WHO), includes physical, social, and mental well-being [11]. The WHO defines "Healthy 
Ageing as the process of developing and maintaining the functional ability that enables well-being in older age" [11] (p. 28) and emphasizes the role of supportive environments. Here, environment includes society, communities, and the home of individuals [11]. Although ageing is not exclusively a biological process, biology is one of the school subjects where students can learn about the procedures and processes of ageing, healthy ageing, and old age.

When talking about age and ageing it is beneficial to subdivide the life of a person into different stages. However, the classical subdivision into the stages childhood, adulthood, and old age is no longer appropriate [12]. A further subdivision of old age seems to be more adequate, since living circumstances and situations vary widely between the age of 65 and 80, interpersonal as well as intrapersonal [13]. The life stage "old age" can be divided into young-old and old-old [14] or the so-called third and fourth age $[15,16]$, and this subdivision will be used in this paper. However, exact age limits between the third and fourth age cannot be set, because of the highly individual nature of ageing processes [17]. Furthermore, a universally acknowledged starting age for being of old age does not exist [18]; often the retirement age is used as a reference point. We apply the commonly used age of 65 years, the former retirement age in Germany $[19,20]$.

\subsection{Images of Old Age and Ageing}

In order to be able to discuss about the challenges and opportunities of a society of long life appropriately, it is necessary to have contemporary ideas about old age and ageing that do justice to the current situation of society [5,21]. Individuals' images of old age are an important starting point. They are defined as ideas about the process of ageing, the state of being old, and conceptions of the social group of older persons [22]. They include images of persons classified as "old" and focus their physical appearance, characteristics, performance, health status, social relationships, inner experience, and socially determined life situations $[23,24]$. Images of old age, held by one person, are not always explicit nor is the individual always aware of them. The images have a formative effect on lifestyles, expectations, and norms and thus have an inhibitory or enabling effect [25]. They influence how older persons are perceived by others and how persons behave towards the elderly. Moreover, the personal ageing process is influenced by images of old age [25]. These external images of old age must be distinguished from self-images of old age. Self-images of old age are ideas that persons have about their own ageing process and about themselves as older persons in the future [22].

Ageism is a term coined by Robert Butler; he defined ageism as another form of bigotry, occurring between different age cohorts [26]. He outlines problems of ageism as prejudice attitudes against elderlies, discriminatory behaviour, and institutional norms, which reduce opportunities of the elderlies on the basis of stereotypes [27]. Ageism does not have to be intended; it often occurs without deliberate intention to impair or harm [28]. Age stereotypes precede age discrimination [29] and are a necessary condition for naming a conduct discriminatory [30]. The internalization of age stereotypes begins in childhood, they develop over time, and are persistent; later on in life these long-standing age stereotypes become self-stereotypes [31]. Ageist attitudes towards elderlies arise in children through observation of their environment. Cultural or family systems of values, information from different forms of media, or everyday experience are some sources for developing ageist attitudes [32].

The effects of age stereotypes are documented in different studies. Individuals with positive self-images of ageing, surveyed up to 20 years earlier, lived longer than individuals, who hold negative beliefs about ageing [33]. Additional, persons with negative age stereotypes, held in earlier life, have an increased risk of experiencing cardiovascular diseases in later life compared to persons with positive images of old age [34].

It is therefore of great importance to raise awareness of the currently predominant images of old age among young persons. Also, in the view of integrating the topics old age and ageing into school teaching the analysis of students' previous knowledge and conceptions about images of old age is an important starting point. In 2010 the Federal Ministry of Family Affairs, Senior Citizens, Women, and Youth reported a research gap in the area of children's and adolescents' age images, 
as there were no pertinent studies available in Germany [22]. In the United States, on the other hand, there is a longer tradition of research in this area using a wide variety of methods [35-39]. For example, descriptions of photos, questionnaires, completing sentences, and the drawing of pictures were used to determine images of old age held by younger persons. They are by no means easily transferable to younger persons today, nor can they be translated into general statements about the attitudes of children towards older persons, since in addition to the research methods, the age groups and sample composition in the studies vary [40]. In addition, the results are embedded in the cultural context [41]. A comparison between young adults (18 to 36 years) attitudes of ageing in the United States and Germany found significant differences. German participants held more negative views on ageing [42]. According to the research synthesis by Gilbert and Ricketts (2008) [32], a cross-comparison between different studies on children's attitudes towards older persons, old age, and ageing (personal and general) is not possible, because of the heterogeneous research conditions. Up to now there exists one comprehensive study, which gives first insights regarding young persons' images of old age in Germany. The qualitative surveys among second graders $(n=29)$ and ninth graders $(n=103)$ show a majority of positive views on older persons, old age, and ageing [23]. They used different methods to collect the age images of the two student groups. The younger students participated in a group discussion with five questions. The older students wrote an essay, either about their own or someone else's life at the age of 70. Since the students were allowed to write freely, the essays contain imaginative and partially also unrealistic descriptions [23]. Another German study included (in the form of a sub-study) a short analysis of students' images of old age $(n=38)$ and also reported predominantly positive images of old age among children and young persons [43]. The students were asked what they consider typical for older persons. More than half of the respondents named exclusively positive attributes, despite being asked about critical characteristics [43]. Although few German studies exist, an extension of the previous studies with a more detailed and more in-depth examination of different facets of the images of old age of young persons is important, in order to describe the current situation in all its diversity. Therefore, we conducted this interview study, including one-on-one interviews and several questions about different topic areas of old age and ageing. So, we were able to ask proceeding questions in the direct conversations and had a chance to obtain a wide range of information from the students.

\subsection{Ageing Education in Schools}

Ageing education is seen as a worldwide imperative-a key component and foundation for successful ageing $[6,44]$. Successful ageing includes life satisfaction $[45,46]$ and is defined as a positive term in contrast to ageism. The education in school can raise awareness, benefit the formation of advantageous views on elderlies, and face students' fear of ageing and death [47]. Ageing education in school offers the possibility to teach basic knowledge about old age and ageing, to initiate contact to older persons, and to give students a chance to express their thoughts, opinions, and fears freely [48]. The book "Learning for Longer Life" [21] is a conceptual framework for American schools, it includes important ageing contents and general learning goals for a balanced view on old age. More concepts for educational frameworks [44] and also possible goals for ageing education [49] have been developed. The content occurring in these frameworks focuses on different aspects of ageing (demographical, political, social, biological, psychological), the own ageing process, relation between young and old, and learning from other generations. The frameworks provide indications of important content areas and can serve as a point of reference for integrating the topics into school teaching. Nonetheless, the perspective of the learners must be taken into account, since students' perspectives are essential starting points for designing teaching environments in science education [50].

Early education on old age and ageing and intergenerational programs help addressing prevalent ageist attitudes [32]. The "Positive Education about Aging and Contact Experiences" (PEACE) model is a theoretical approach, which emphasizes education and positive contact to elderlies in order to reduce ageism [51]. Establishing ageing as a concrete educational content in school is elementary, in order to 
achieve multifaceted images of old age and a life-span perspective of students [5]. Positive effects of contact with older persons and knowledge of ageing on the attitudes of younger adults were suggested in an American study [52]. Knowledge about old age and ageing is, besides the direct contact to older persons, an important concern. A possible correlation between knowledge and attitudes towards ageing is at the focus of different studies. These studies do not exclusively include the age group of school students and show various results. On the one hand, associations between knowledge of ageing and attitudes towards older persons appear to be unrelated [53] or only weak associations between more knowledge and a positive attitude were found [54]. On the other hand, a study from Slovenia with secondary school students shows that students with less knowledge often have a negative attitude towards older persons [55]. These findings go with a study including older participants from Great Britain. Here, participants with more knowledge show a lower level of ageism. In addition, there is an increase in knowledge after participating in an ageing awareness workshop. However, this increase is not accompanied by a change of avoidance feelings towards ageing and older persons, and discrimination [56]. Another study with university students found that knowledge and contact with older persons affect ageism indirectly conveyed through their effect on fear. Students with more knowledge about ageing tend to be less fearful and this decrease in fear directly reduced ageist attitudes [57]. Positive changes in attitudes towards ageing were also shown after students participated in gerontology courses [58]. Other important conclusions in this context are that knowledge should be presented in a balanced way instead of one-sided images of old age and that ageing education should be started in childhood as early as possible $[58,59]$.

The binding educational standards of the Federal Republic of Germany state that school education has the obligation to educate students in order for them to become responsible citizens, who can participate in social and political life [60]. This educational mission also includes teachers, who are obligated to support the learners in their solidary action in a social context. Respect for human rights and tolerance have to be promoted [60]. Older persons are thus inevitably included in the interdisciplinary teaching goals, even if they are not explicitly mentioned as a group. They have to be represented in the context of social life. Science education, and thus biology, is also involved in this mission. To date, however, the topic old age has not been anchored in the school curriculum of North-Rhine Westphalia, which is a German state, and is therefore not explicitly addressed in class. An analysis of curricula from four further German states shows that age and ageing, demographic change, and generational relations are hardly taken into account [23]. In addition, there are one-dimensional orientations, which show a negative and partly stereotype-laden representation of old age. Despite the naming of wisdom and life experience in old age, few competencies and opportunities of old age are mentioned. It seems like the social potential of older persons is not perceived, since the representations are rather one of passivity [23]. Furthermore, our own previous study of textbooks of biology and politics $(n=37)$ being approved for the German state North Rhine-Westphalia showed that issues dealing with old age and growing old are inadequately addressed, both in regard to quantity and quality of the material. Moreover, the majority of analyzed textbooks do not contain texts or illustrations about older persons or ageing at all [61]. This even more demonstrates the urgency of adequately integrating the topic into school education.

\subsection{Aim of the Present Study}

In our study, the focus is on the initial situation and thus the students' concepts on the topics of old age and ageing. By conducting individual interviews, it is possible to ask precise questions and discuss the answers to clarify young persons' points of view, in order to receive a detailed insight in the different ideas of the learners. On the basis of the students' concepts, possible integration approaches for teaching in secondary schools are outlined. The aim of this study is to collect and describe learners' current images of old age (regarding self-images and external images) in order to identify initial starting points for integrating the topics of old age and ageing into school practice. 


\section{Method}

The research design is based on qualitative methods in order to get an insight into the images and concepts of old age and ageing students hold. The objective is to analyse and interpret student statements and thus examine and explore their conceptions.

The sample consists of 10 students, four female and six male, from the ninth grade of the lower secondary school (Realschule) based in North Rhine-Westphalia in Germany. In the following, the gender is indicated by the abbreviations " $\mathrm{m}$ " (male) or " $\mathrm{f}$ " (female) after the identification code of each student (e.g., S1_m). The students are between 15 and 16 years old $(M=15.2)$. Six out of 10 interviewees have a migrant background, four of whom have learned German as a second language and two are bilingual. The sample composition corresponds approximately to the percentage of students with migrant histories in secondary schools in North-Rhine Westphalia, which is about $50 \%$ [62]. The sample group was chosen because they already had experiences with older persons in their lives that they can express properly and reflect upon. Moreover, they are about to graduate after 10th grade-entering professional life with their current individual conceptions.

The guideline-supported interviews are divided into different content parts, focussing on the following aspects: Determination of old age, images of old age like physical appearance, characteristics, behaviour, daily life, or health status, self-images that refer to the lives of students at the age of 65 years, and the ageing process. Previous test interviews with 15 -year-old students helped to adapt the guideline. Only linguistic adaptions were made in order to improve the questions and make them more comprehensible for young persons, especially for second-language German speakers. With the help of the revised version of the guideline, one-on-one semi-structured interviews were conducted. This allowed the interviewer to react flexibly to information provided by the interviewees and not to disturb the narrative flow. The sequencing of the questions was not strictly regulated. However, the interviewer assured that each student got the opportunity to talk about every content part. The guideline helped the interviewer to use the same wording. During the course of the interviews, it was ensured that the questions were understood by all the interviewed students in terms of content. The students did not report language barriers or communication problems, nor did we find any during the analysis. All interviews were conducted by an adult under the age of 30 years. The interviews were audio recorded, completely transcribed, and anonymised. The 10 students participated voluntarily in the interview study.

A systematic processing of all statements was made. The analysis of the interview transcripts was limited to those sequences concerning the images of old age, i.e., individual student ideas about the process of ageing, the state of being old, or older persons. The statements of the learners are evaluated by qualitative content analysis [63,64] using the software MAXQDA 2018 [65] for a systematic analysis. Based on the interview transcripts, a coding frame was created with a combination of a priori and emergent categories. As a first step, main categories were constituted, focussing on ageing and images of old age (external image and self-image), the life phase old age, appearance, characteristics, conduct, daily life, and health status. These main categories were generated a priori and are based on theoretical considerations, with reference to publications on old age and ageing (see Section 1.1; i.e., [22-24]). On the basis of these main categories, subcategories were inductively formed by subsumption. The emergent subcategories were generated data-driven on the basis of the interview transcripts and provide a detailed overview of the students' statements. To assess the reliability (intersubjectivity), a group of biology didactics experts, consisting of two professors and five research assistants, discussed and adapted the coding frame. Primarily, the discriminatory power between the categories and the traceability was discussed. The final coding frame consists of main categories (e.g., determination of old age), subcategories (e.g., biological changes), descriptions of the subcategories (e.g., physical condition of a person, state of health, and/or natural ageing processes), prototypical text passages (e.g., S1_m: “From the age when she [old person] begins to have physical problems, maybe pain in the bones. Yes, actually, from that or from the time when he can't do things he [old person] used to do or things are difficult for him that used to be easy for him"), related leading 
questions (e.g., "When is a person old?"), and coding rules. In a final step, for establishing consistency, the first author and a second independent rater, a teacher, who is working as a research assistant, coded the entire interview material, following the coding frame strictly. Differing classifications and alternate interpretations were discussed. Together, a final coding of the interview material was decided upon, granting a total agreement regarding the interpretation.

One limitation of the method is that one could argue the results are only applicable for the interviewed group of students. However, the aim of this study is not to generalize findings, but to find attitudes and images that could also occur in other groups of students, to give starting points for a didactical discussion. By interviewing a heterogeneous sample, an attempt was made to obtain the broadest possible range of information. The aim is to describe the actual state and to derive initial implications for teaching from the students' statements. Another limitation is social desirability, i.e., when responses are not personal, but are based on social norms. Efforts were made to create trust through an interview situation that takes place in a familiar environment of the respondents. The students were also given transparent information about the study in advance and were made aware that they can freely express their opinion and that their data will be treated anonymously and confidentially.

\section{Results}

\subsection{Description of the Categroy System}

The formed main categories and subcategories, listed in Table 1, are described and summarized below to give an insight into the students' perceptions. If useful, meaningful examples are added to the descriptions, each labeled with a student code for an exact allocation to one of the interviewees (see Table 1).

The students use combinations of the subcategories (1.1-1.4, see Table 1) to describe as of when a person is considered to be old, i.e., for the determination of old age. Significant indicators of old age the students use are biological changes, which refer to the natural ageing process (white hair, wrinkles) and the reduction of the health status, including mainly physical losses. The calendar age is another often used indicator for the determination. For the interviewed students, the beginning of old age is between the 50th and 70th year of life. Therefore, persons who are in their adulthood are sometimes already considered to be of old age. Beside the physical losses, a general dependence on other people is also addressed. Social age, as a reference to membership of a social group, e.g., grandparents, is seldom addressed as an indicator of old age. The following statement of one interviewee shows the combination of the subcategories calendar age and biological changes: "60. Yes 60." (S2_m). In addition, he mentions: "In terms of appearance, for example, when you get wrinkles or when you can no longer move so fast or so much." (S2_m). Besides mentioning a concrete age, reference is also made to appearance and physical condition.

As typical features of older persons the students name among other things the external appearance, which includes clothing, accessories, jewelry, or hairstyle, in addition to natural changes such as wrinkles, tooth loss, bald head, or grey hair. The following student statements can be attributed to the subcategory external appearance: "[...] they [older persons] still wear pretty old clothes even though they have newer ones these days, but they stick with their old stuff." (S9_m); "[...] mostly knitwear or just shirts [...]." (S9_m). Apart from the style of clothing, hair is also mentioned by the students, as this statement shows: "[ ... ] a lot of older persons, either they have no hair, or their curls are turned up." (S10_f). Another subcategory of the main category typical features of older persons is the language usage that is different from young persons' usage and sometimes incomprehensible for them. According to the students, youth language is not understood by older persons, which causes comprehension problems. Older persons express themselves more objectively and formally. In addition to the above-mentioned subcategories, leisure time behavior is also highlighted as typical. Physical activities such as cycling or walking, social activities such as conversation and storytelling, and home cooking or sewing are 
mentioned. Other important characteristics of older persons for the students are physical constraints (exhaustion, physical strain, limited mobility, backaches), mind (forgetfulness, missing knowledge), and general impairments (loss of independence, dependence on help). Summarized under the subcategory impairment are statements like: "That they're [older persons] always so exhausted and can't do everything themselves." (S3_f); "[ ... ] the older you get, the more help you need, so you become a kid again somehow. Because when you're very small, you need a lot of attention, someone has to take care of you and the older you get, that happens again, so that's a circle." (S3_f). This statement highlights general impairments. Life is described as a circle in which the elderly become like children again and are dependent on help and care. Almost always different aspects, which fall into different subcategories, are addressed by the interviewees in one statement, as the following example shows: "[ ... ] white hair, wrinkled skin, maybe that you need a walking stick or a walking aid, for example, that you can't get up on your own or that you always need help with something, even if it's only making a sandwich or something like that." (S8_f).

Table 1. Category system with separation into the main categories and the corresponding subcategories.

\begin{tabular}{|c|c|c|}
\hline & Main Categories & Subcategories \\
\hline 1. & Determination of old age & $\begin{array}{l}\text { 1.1. Biological changes } \\
\text { 1.2. Calendar age } \\
\text { 1.3. Social age } \\
\text { 1.4. Dependence on help }\end{array}$ \\
\hline 2. & Typical features of older persons & $\begin{array}{l}\text { 2.1. External appearance } \\
\text { 2.2. Language style } \\
\text { 2.3. Activities } \\
\text { 2.4. Impairment }\end{array}$ \\
\hline 3. & Characteristics of older persons & $\begin{array}{l}\text { 3.1. Kind } \\
\text { 3.2. Unfriendly } \\
\text { 3.3. Experienced }\end{array}$ \\
\hline 4. & Older persons from the social environment & $\begin{array}{l}\text { 4.1. Relatives } \\
\text { 4.2. Circle of } \\
\text { acquaintances } \\
\text { 4.3. Strangers }\end{array}$ \\
\hline 5. & Everyday life of older persons & $\begin{array}{l}\text { 5.1. With limitations } \\
\text { 5.2. Without limitations }\end{array}$ \\
\hline 6. & Conduct of older persons & $\begin{array}{l}\text { 6.1. Thoughtfulness } \\
\text { 6.2. Serenity } \\
\text { 6.3. Sociability }\end{array}$ \\
\hline 7. & Problems of older persons & $\begin{array}{l}\text { 7.1. Body } \\
\text { 7.2. Mind } \\
\text { 7.3. Social life } \\
\text { 7.4. General problems }\end{array}$ \\
\hline 8. & Self-image of old age & $\begin{array}{l}\text { 8.1. With limitations } \\
\text { 8.2. Without limitations }\end{array}$ \\
\hline 9. & Assessment of one's own ageing process & $\begin{array}{l}\text { 9.1. Positive } \\
\text { 9.2. Negative } \\
\text { 9.3. Neutral }\end{array}$ \\
\hline
\end{tabular}

Characteristics of older persons can be subdivided into the subcategories kind, unfriendly, and experienced. Broad descriptions of kindness like nice, friendly, cordial, dear, or helpful are stated. In contrast, unfriendliness is seldom mentioned. Getting angry quickly is a statement made by two respondents. Knowledge and life experience are other characteristics with positive connotations that are named by the students. 
The fourth main category regards older persons from the social environment of the students. The interviewees should name older persons they know from their social environment. The subcategories include relatives, the circle of acquaintances, and strangers. It becomes apparent that persons who are under the age of 65 years are also named, for example parents, teachers, or shop assistants. As expected, relatives come to mind first and are the most frequently mentioned group. Besides grandparents, great-grandparents are also listed by the students. Older persons, who are shown in the media, are named once.

The everyday life of older persons is another main category. While talking about the everyday life of older persons the students often referred to the body, social life, and leisure activities. These statements were coded as "with limitations" or "without limitations" in regard to the body/physical condition, social life, and leisure activities. In order to illustrate the allocation, here is a statement of a student: "Yes, so they get up, take medication, then maybe go for a walk, read the newspaper, then maybe grandchildren visit him, yes, it's a bit monotonous. So, I find it monotonous, as an old person you don't have so many possibilities to do something, I think." (S6_m). On the one hand, there are restrictions of the physical condition seen in the intake of medication (body/physical condition-with limitations), on the other hand there are walks mentioned, which indicate physical activity (body/physical condition-without limitations). The social life is characterized by family contact (social life-without limitations). However, the leisure activities as a whole are seen rather limited and are described as monotonous (leisure activities-with limitations). All in all, the everyday life of older persons is described as very calm and regular. Four students (S4_f, S5_m, S8_f, S10_f) use different everyday descriptions depending on how old or fit the person is. According to them, a younger or fit old person can do more in everyday life and is not as restricted in life. Loneliness in old age is not directly mentioned, but a monotonous or boring life. According to six students (S1_m, S2_m, S3_f, S6_m, S8_f, S10_f), activities are limited, elderly persons cannot or do not want to go out anymore. However, students mention visits to the grandparents, so there are still few social activities. Other social contacts beside the family, like friends, are seldom stated. The daily routines of the own grandparents serve as basis and support for the description of older persons' everyday life.

Descriptions of the conduct of older persons can be subdivided into the subcategories thoughtfulness, serenity, and sociability. Personality traits that determine behavior are described by the respondents. The conduct is seen as calm, serene, and relaxed. Actions are deliberately considered by older persons and, according to the students, they act more cautiously. Comparisons are drawn with younger persons because, according to the students, older persons are more serious and disciplined, as evidenced by the mentioned thoughtfulness and deliberateness. A social compatibility of older persons is also stated, because sociability and a friendly behavior are described.

The students were directly asked about problems of older persons at an advanced stage of the interviews. Here, the subcategories body, mind, social life, and general problems were formed. In Table 2, the described problems are shown in detail. With regard to the body it becomes clear that instead of naming diseases, the students rather describe the symptoms briefly, i.e., possible physical problems that older persons may have. For example, a decrease in blood cell production that leads to a limited mobility of the hand was described as a common problem among older persons by one student. The name of the disease was unknown to the student and it remains questionable, which disease she was referring to. Furthermore, it becomes apparent that the student linked the two symptoms without considering the effects of a decreased blood cell production on the whole organism (S10_f). One student distinguishes between minor diseases and major diseases: "I think in the course of age one gets already a few minor illnesses, one is lucky if one does not get so major [illnesses], but a few minor [illnesses], for example diabetes or so, one gets certainly." (S3_f). She identifies different diseases and sees the tablet intake for diabetes as uncomplicated and therefore the disease as "minor" and not so severe: "Yes, for example, when your lungs fail, when your body fails, when your heart fails and so on, these are major diseases, but diabetes where you only have to swallow one tablet is not that bad." (S3_f). Although oral antidiabetic drugs may be used to treat type 2 diabetes, it should not be 
considered a mild or "minor" disease of old age, as severe secondary and concomitant diseases can occur [66]. The mental state is connected, besides limitations like forgetfulness or dementia, to fear and war trauma. Social problems are not mentioned often, especially in contrast to the physical problems, which are predominant. Altogether, the causes of diseases are not discussed in the slightest. Furthermore, generalized statements are made.

Table 2. Mentioned problems of older persons in the interviews, divided in four subcategories.

\begin{tabular}{|c|c|}
\hline Body & $\begin{array}{l}\text { - } \quad \text { cardiovascular disease (heart problems, high blood pressure, blood disease) } \\
\text { - } \text { diabetes (metabolic disorder) } \\
\text { - } \quad \text { organ failure of lungs, kidneys } \\
\text { - } \quad \text { sensory impairment (hearing problems, impaired vision) } \\
\text { - } \\
\text { restriction of the musculoskeletal system (limitation of movement, bone fragility, back problems) }\end{array}$ \\
\hline Mind & $\begin{array}{l}\text { - } \text { mental limitations (dementia, Alzheimer's, forgetfulness) } \\
\text { - } \quad \text { fear (of pain, death) } \\
\text { war trauma }\end{array}$ \\
\hline Social Life & $\begin{array}{ll}\text { - } & \text { boredom } \\
\text { - } & \text { being overlooked (not getting attention) }\end{array}$ \\
\hline General Problems & $\begin{array}{l}\text { - } \quad \text { higher risk of illness } \\
\text { - } \quad \text { effects of the previous lifestyle } \\
\text { - } \quad \text { needical care (medication, visiting the doctor) } \\
\text { - } \quad \text { stress sensitivity }\end{array}$ \\
\hline
\end{tabular}

The self-image of old age of students, which refers to students' conceptions of their life with the age of 65 years, is a look ahead into the future. The self-image of old age often contains the aspects relaxation and family life, especially having own grandchildren. Further statements can be divided into the subcategories "with limitations" or "without limitations". Physical fitness and the social life are assessed positive. Staying fit is considered important by two students (S6_m, S7_m) in order to be in a good physical condition and not being dependent on help from others. Only one student (S9_m) talks about having a bad health condition, because his current lifestyle is unhealthy. Another student (S4_f) mentions the anxiety of not being able to move well, in this context, but adds that she will be hiking a lot and will be out in the nature. The state of health is considered positive by the other students. Social life, including family reunion or meetings with friends, is described by all students except for one student (S9_m), who prefers a life without own children. Possibilities of leisure activities are seen as limited by two students (S3_f, S6_m). Apart from activities that, according to the students, one will do in old age, such as going for walks and being in nature, two students (S3_f, S6_m) speak of monotony and boredom in old age, as one cannot do a lot and is excluded from everyday life.

The assessment of one's own ageing process has different gradations, ranging from positive over neutral to negative attitudes. Predominantly ageing is seen as a natural process, which is normal and inevitable. According to five of the students ageing is part of life for everyone. The statement of one interviewee shows this neutral attitude: "So I am neutral, since it is not a problem for me to get older, because that is what every person becomes and that is not some kind of disease or something, but simply something natural." (S2_m). The accumulated life experience and an increasing level of knowledge are mentioned as positive aspects of being of old age. Negative aspects refer to the students' feelings, that in old age most of your life lies behind you and there are only little exciting things to come. They regard their current living situation and the nearer future as more exciting and eventful. Furthermore, there is the fear that time passes too quickly, and you miss something in life. Hypothetical infinite life, however, is not considered to be a better alternative by one student (S9_m), because loved ones would die, and he would rather grow old with them. 
Besides the results reported above referring to the category system, it is noticeable that during the interviews, the students often use their own grandparents as examples in their statements to describe circumstances. For the most part, there is no generalization on older persons as a whole, but reference is made to only a few individual persons. It can be said that older persons are not considered to be a homogenous group. The qualitative evaluation did not find major differences in the images of old age between students with or without migrant backgrounds. However, this observation cannot be generalized and might only be true for this sample group.

\subsection{Superordinate Results}

In addition to the results listed above, which refer to the individual categories of the developed category system, there are superordinate aspects that apply to more than one category.

The first aspect is the predominant negative description of the body of older persons, i.e., the limited physical functionality, which can be found in the main categories 1-Determination of old age, 2-Typical features of older persons, 5-Everyday life of older persons, and 7-Problems of older persons. The students most frequently addressed the limited physical functionality, when being asked directly about problems of older persons, even though no direct reference to physical functionality or body was made in the questions (see Table 2).

Another superordinate aspect is that the effects of the current lifestyle on old age are hardly taken into account and are only mentioned by three students (S1_m, S6_m, S9_m). For the main categories 8-Self-images of old age and 7-Problems of older persons, no reference is made to the effects of one's own lifestyle or the causes of limitations in old age.

Furthermore, the main category 7-Problems of older persons and the subcategories 1.4-Dependence on help and 2.4-Impairments reveal a third aspect, namely that only rudimentary knowledge about age-related diseases is present. Names of diseases are hardly used in the entire interviews, but rather descriptive elements.

Another aspect is that social aspects are hardly considered and that there is mainly contact with older persons within the family (grandparents). Contact with older persons outside the family is hardly or not at all present (see main category 4-Older persons from the social environment). No reference is made to partnerships in old age, social activities, or social commitment. Only contact with the family and grandchildren is highlighted (see main category 5-Everyday life of older persons). Social isolation and exclusion of older persons from society are not directly mentioned in all but one interviews, only one student (S3_f) addressed a disregard in society. However, boredom, tedium, and less leisure activities are mentioned more frequently (see main category 5-Everyday life of older persons).

A fifth superordinate aspect is the positive self-image in comparison to an external image of old age, which also includes negative elements that become apparent in various subcategories (see subcategories 1.4, 2.4, 3.2, and 5.1 in Table 1).

As a last aspect it should be noted that the fourth age is hardly ever mentioned by the students during the entire interviews. Nevertheless, in some cases, the description of the daily life of older persons show a differentiation between the third and fourth age (see main category 5-Everydalife of older persons). In further descriptions, the students even refer to age groups under 65 years as being of old age (see main categories 1-Determiniton of old age and 4-Older persons from the social environment).

\section{Discussion}

The results of the interview study give a first impression of the status quo of students' conception of elderlies, old age in general, and their own ageing process. Didactic guidelines for school teaching must tie in with these perceptions predominant among students and regard them as a starting point for teaching and learning processes [50]. Misconceptions and missing aspects give first indications of urgent topics that need to be taught. The focus of the discussion will be on results, which hold implications predominantly for biology education. A link to other subjects, for example social science, is expressly desired and necessary in order to address the topics of old age and ageing interdisciplinary. In the 
following, different teaching approaches will be derived from the previously mentioned superordinate results of the interview study (see Figure 1).

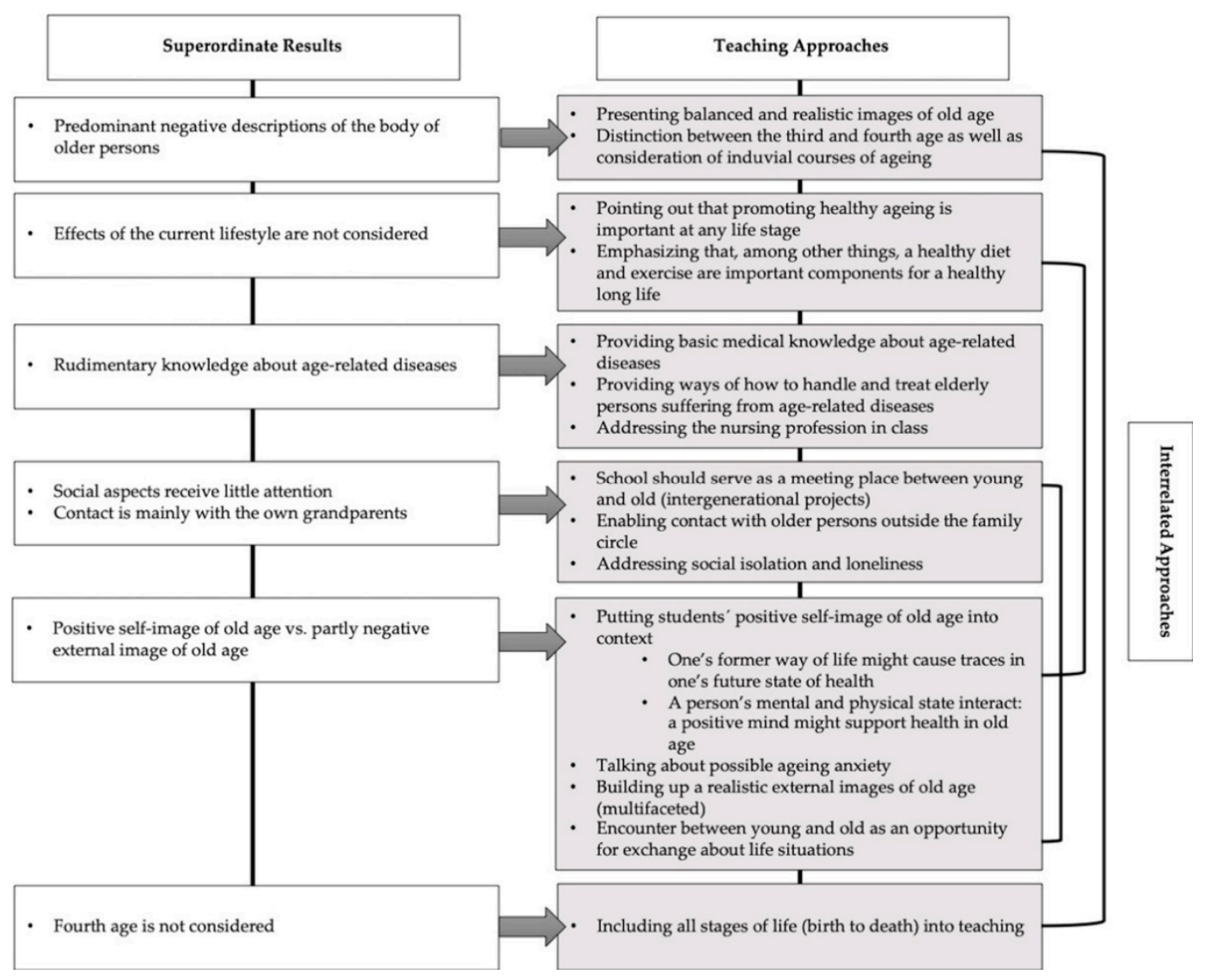

Figure 1. Teaching approaches derived from the students' statements of the interview study. Interrelated approaches are marked by connection lines on the right.

The predominantly one-sided negative descriptions of the body of older persons have an obstructive effect on the view on and contact with older persons and one's own ageing. Many physical skills of older persons are denied by students. Their generalized statements include persons of the third age. This stands in contrast to the findings of the German Ageing Survey of the year 2014. The subjective assessment of the state of health is rated as very good or good by about half of the 65-74-year-old (third age) respondents. The students underestimate this group's state of health. At an older age of approximately 80 years and older, functional health, which includes the ability to cope with everyday life, decreases significantly $[67,68]$. The students' assessments are more consistent with the findings regarding this age group. Hence, school practice needs to create and also promote balanced images of old age, in which the age of 65 to 80 years is, beside physical complaints, also linked to fitness and mobility. The emphasis on individual ageing processes and multifaced images of old age [5] is important in order to counteract generalizing statements and the general denial of skills. In addition to knowledge transfer and the presentation of realistic images of old age an active deconstruction of existing age stereotypes is necessary in school. Statements like "It is typical that they [an old person] just can't move that well anymore" (S10_f) and "old age, [meaning] not being fit anymore, needing help" (S6_m) are manifestations of the persisting age stereotype that older persons are frail, which inhibits the participation of older persons in society and also effects the personal ageing process negatively. A head-on discussion of age stereotypes in class with questions like "What are age stereotypes?", "Is the statement 'old people are frail' true for all, most or some older persons?", "How do age stereotypes 
effect older persons?" and "How do they affect you now or in your future?" can help to sensitize students and deconstruct age stereotypes.

The effects of the current lifestyle, which also influence the well-being in old age, are further relevant issues. Thus, healthy ageing and prevention at a young age is an important concern for schools, in order to create a good foundation for the lifelong process of ageing. Effects of one's lifestyle at a young age on later years should be discussed appropriately, without increasing the fear of age-related diseases. Biology education can build awareness for individual courses of ageing, which are linked among other things, to the lifestyle and hereditary predispositions. Preventive measures, which include a healthy diet and physical and mental activity, as well as a realistic assessment and diagnosis of age-related limitations, are important for a healthy ageing [69]. Therefore, ageing education can be a connecting point for healthy eating and exercise.

In addition, information on typical geriatric disorders affecting body or mind should be provided, since the development and causes of specific clinical pictures are hardly described or mentioned by the students. The on-going controversial discussion about defining ageing itself as a disease (see [70-72]) can be brought up in the classroom. This grants the opportunity to discuss the definition of ageing as a disease, and possible effects on the development and marketing of anti-ageing medicine [73]. Education on common age-specific diseases like cardiovascular disease, Parkinson's disease, late life-depression, and dementia, especially Alzheimer's, can be useful as subject matters in higher grades to take away unfounded fears and to dispel misconceptions. To integrate the current state of knowledge of the learners into the lesson planning a query of the previous state of knowledge can be essential to specifically address gaps. Besides diseases the handling of persons in need of care can also be addressed. In Germany, a large proportion of elderly persons in need of care are nursed at home by their own family members [74]. The nursing profession with its fields of activity and patient groups can be a follow-up topic in terms of vocational training, as the demand for skilled nursing personnel will continue to increase.

The social aspect is another issue that must not be neglected. School can serve as a place for encounters for the young and old generation to strengthen the intergenerational relationship and promote the exchange, since not all students have contact with their grandparents, as it was the case in this sample. The interaction with older persons can show similarities between young and old persons and can take fear of contact. Structured programs can be carried out in different school grades. Different studies emphasize that contact to elderlies in intergenerational programs can have a positive impact on children's perceptions towards older persons [75-77].

The disparity between mainly positive age self-images and images with limitations of older persons in general can be confronted by introducing a realistic age image. Positive self-images are not bad per se, because persons with a positive attitude on their own ageing become healthier and more active as they grow older and live longer than persons, who have a negative view on their own ageing [31,33]. In addition, it should be shown in class that a good state of health in old age is not independent from previous life choices. A lifestyle that is detrimental to health and is maintained over a long period of time will show its traces in old age. However, the partly negative images of others hold the danger of amplifying the denial of competencies and quality of life of older persons which might result in aging anxiety. By building upon the positive self-images and introducing realistic age images, school teaching can have an adapting effect on the students' expectations regarding their personal ageing process and prevent the underestimation of older persons in general. In order to develop a differentiated and realistic image of old age, the own grandparents can just serve as a starting point. In addition, as mentioned before possibilities for direct contact with unfamiliar elderlies should also be created in order to broaden one's image of old age and ageing.

The high age is hardly or not at all addressed directly by the students. In biology education, all life phases from birth up to old age and death can be discussed. Students can learn about the natural and individual ageing processes and the focus is broadened up to all stages of life. A discussion of biological age should not take place detached from other perspectives on age and ageing. Simply linking 
calendrical age to biological age is not enough; social, psychical, and functional age should also be addressed.

The teaching approaches described above differ from the previous proposals [21,44] mainly in the fact that our approaches were deduced directly from student statements. These student derived approaches correspond to the topic areas biological, physical, physiological, and social from Couper and Pratt [21]. The results of our analysis also suggest additional topics, for example teaching about age-related diseases, considering the different life situations in the third and fourth age, and facilitating an exchange with old persons outside the family circle. To consider ageing as a lifelong, individual and natural process in addition to the above-mentioned contents is an important concern in all teaching approaches.

All in all, the consideration of images of old age gives a first approach for an ageing education in school. Future research including other age groups of students can bring more insights into the images of old age in different grades. Longitudinal studies may reveal the development of individual images of old age over time. In addition, interviews with students from other school types may indicate whether students on different educational levels hold different images of old age. Moreover, a discussion with students would reveal how the students interact in regard to different views on the topics old age, ageing, and ageism. In addition to the student perspective, the teachers' perspective on elderly persons is also an important point of reference, as it can influence the teaching process. Even if the present article provides initial hints on how to integrate issues of old age and ageing into teaching, more research is needed to develop a comprehensive approach to school practice. This further research should not only include students' views, but also that of teachers and experts in gerontology in order obtain a comprehensive overview of how best to address the topics of old age and ageing in class.

Author Contributions: Conceptualization, F.G. and K.S.; Methodology, F.G.; Project administration, K.S.; Supervision, K.S.; Visualization, F.G.; Writing—original draft, F.G.; Writing—review \& editing, F.G. and K.S. All authors have read and agreed to the published version of the manuscript.

Funding: This research received no external funding.

Acknowledgments: We want to thank Isabel Marie Breuer for her help in conducting the interviews with the students as part of her master thesis and Christoph Körner for his support as an independent rater.

Conflicts of Interest: The authors declare no conflict of interest.

\section{References}

1. United Nations, Department of Economic and Social Affairs. World Population Ageing 2015; (ST/ESA/SER.A/390); United Nations: New York, NY, USA, 2015.

2. Höhn, C.; Mai, R.; Micheel, F. Demographic Change in Germany. In Demographic Change in Germany: The Economic and Fiscal Consequences; Hamm, I., Seitz, H., Werding, M., Eds.; Springer: Berlin, Germany, 2008; pp. 9-33.

3. Mai, R. Demographic change in Germany. Eur. View 2008, 7, 287-296. [CrossRef]

4. Statistisches Bundesamt (Destatis). Bevölkerung im Wandel. Annahmen und Ergebnisse der 14. Koordinierten Bevölkerungsvorausberechnung; Statistisches Bundesamt: Wiesbaden, Germany, 2019.

5. Kruse, A.; Wahl, H.-W. Zukunft Altern. Individuelle und gesellschaftliche Weichenstellungen; Spektrum Akademischer Verlag: Heidelberg, Germany, 2010. [CrossRef]

6. McGuire, S.L. Aging Education: A Worldwide Imperative. Creat. Educ. 2017, 8, 1878-1891. [CrossRef]

7. Baltes, M.M.; Baltes, P.B. Gerontologie: Begriff, Herausforderung und Brennpunkte. In Alter Und Altern: Ein Interdisziplinärer Studientext Zur Gerontologie; Staudinger, U.M., Mittelstraß, J., Baltes, P.B., Eds.; De Gruyter: Berlin, Germany, 1994; pp. 1-34.

8. Pohlmann, S. Das Alter im Spiegel der Gesellschaft; Schulz-Kirchner Verlag: Idstein, Germany, 2004.

9. Schulz-Nieswandt, F.; Köstler, U. Bürgerschaftliches Engagement im Alter: Hintergründe, Formen, Umfang und Funktionen; Kohlhammer Verlag: Stuttgart, Germany, 2011.

10. World Health Organization (WHO). Global Strategy and Action Plan on Ageing and Health; World Health Organization: Geneva, Switzerland, 2017. 
11. World Health Organization (WHO). World Report on Ageing and Health; World Health Organization: Geneva, Switzerland, 2015.

12. Guillemard, A. Equity between Generations in Aging Societies: The Problem of Assessing Public Policies. In Aging and Generational Relations over the Life Course; Hareven, T.K., Ed.; De Gruyter: New York, NY, USA, 1996; pp. 208-224.

13. Smith, J.; Zank, S. Forschungsaktivitäten im Themenfeld "Hochaltrigkeit". In Das hohe Alter-Konzepte, Forschungsfelder, Lebensqualität. Expertisen zum Vierten Altenbericht der Bundesregierung; Deutsches Zentrum für Altersfragen (DZA), Ed.; Vincentz Verlag: Hannover, Germany, 2002; pp. 97-227.

14. Neugarten, B.L. Age Groups in American Society and the Rise of the Young-Old. Ann. Am. Acad. Political Soc. Sci. 1974, 415, 187-198. [CrossRef]

15. Laslett, P. The Third Age, The Fourth Age and The Future. Ageing Soc. 1994, 14, 436-447. [CrossRef]

16. Laslett, P. Das dritte Alter: Historische Soziologie des Alterns; Juventa-Verl.: Weinheim, Germany, 1995.

17. Backes, G.M.; Clemens, W.; Künemund, H. Lebensformen und Lebensführung im Alter-Objektive und subjektive Aspekte des Alter(n)s. In Lebensformen und Lebensführung im Alter; Backes, G.M., Clemens, W., Künemund, H., Eds.; VS Verlag für Sozialwissenschaften: Wiesbaden, Germany, 2004; pp. 7-22.

18. Kite, M.E.; Wagner Smith, L. Attitudes toward Older Adults. In Ageism: Stereotyping and Prejudice against Older Persons; Nelson, T.D., Ed.; MIT Press: Cambridge, MA, USA, 2002; pp. 129-161.

19. Eurostat (European Commission). Ageing Europe. Looking at the Lives of Older People in the EU; Publication Office of the European Union: Luxembourg, 2019. [CrossRef]

20. Wurm, S. Lebensalter, Drittes und Viertes im Dorsch Lexikon der Psychologie. Available online: https: //dorsch.hogrefe.com/stichwort/lebensalter-drittes-und-viertes (accessed on 30 July 2020).

21. Couper, D.P.; Pratt, F. Learning for Longer Life. A Guide to Aging Education for Developers of K-12 Curriculum and Instruction Materials; National Academy for Teaching and Learning about Aging: Denton, TX, USA, 1999.

22. Federal Ministry for Family Affairs, Senior Citizens, Women and Youth (BMFSFJ). Sechster Bericht zur Lage der älteren Generation in der Bundesrepublik Deutschland-Altersbilder in der Gesellschaft; Drucksache 17/3815; Deutscher Bundestag: Berlin, Germany, 2010.

23. Amrhein, L.; Backes, G.M.; Harjes, A.; Najork, C. Alter(n)sbilder in der Schule; Springer Fachmedien: Wiesbaden, Germany, 2014. [CrossRef]

24. Schmidt-Hertha, B.; Mühlbauer, C. Lebensbedingungen, Lebensstile und Altersbilder älterer Erwachsener. In Individuelle und kulturelle Altersbilder: Expertisen zum Sechsten Altenbericht der Bundesregierung; Berner, F., Rossow, J., Schwitzer, K.-P., Eds.; VS Verlag für Sozialwissenschaften: Wiesbaden, Germany, 2012; pp. 109-149.

25. Rossow, J. Einführung: Individuelle und kulturelle Altersbilder. In Individuelle und kulturelle Altersbilder: Expertisen zum Sechsten Altenbericht der Bundesregierung; Berner, F., Rossow, J., Schwitzer, K.-P., Eds.; VS Verlag für Sozialwissenschaften: Wiesbaden, Germany, 2012; pp. 9-24.

26. Butler, R.N. Age-Ism: Another Form of Bigotry. Gerontologist 1969, 9, 243-246. [CrossRef]

27. Butler, R.N. Ageism: A Foreword. J. Soc. Issues 1980, 36, 8-11. [CrossRef]

28. Levy, B.R.; Banaji, M.R. Implicit Ageism. In Ageism: Stereotyping and Prejudice against Older Persons; Nelson, T.D., Ed.; The MIT Press: Cambridge, MA, USA, 2002; pp. 49-75.

29. Ayalon, L.; Tesch-Römer, C. Introduction to the Section: Ageism-Concept and Origins. In Contemporary Perspectives on Ageism; Ayalon, L., Tesch-Römer, C., Eds.; Springer International Publishing: Cham, Switzerland, 2018; pp. 1-10.

30. Voss, P.; Bodner, E.; Rothermund, K. Ageism: The Relationship between Age Stereotypes and Age Discrimination. In Contemporary Perspectives on Ageism; Ayalon, L., Tesch-Römer, C., Eds.; Springer International Publishing: Cham, Switzerland, 2018; pp. 11-31.

31. Levy, B.R. Mind Matters: Cognitive and Physical Effects of Aging Self-Stereotypes. J. Gerontol. B Psychol. 2003, 58, P203-P211. [CrossRef]

32. Gilbert, C.N.; Ricketts, K.G. Children's Attitudes Toward Older Adults and Aging: A Synthesis of Research. Educ. Gerontol. 2008, 34, 570-586. [CrossRef]

33. Levy, B.R.; Slade, M.D.; Kunkel, S.R.; Kasl, S.V. Longevity Increased by Positive Self-Perceptions of Aging. J. Pers. Soc. Psychol. 2002, 83, 261-270. [CrossRef]

34. Levy, B.R.; Zonderman, A.B.; Slade, M.D.; Ferrucci, L. Age Stereotypes Held Earlier in Life Predict Cardiovascular Events in Later Life. Psychol. Sci. 2009, 20, 296-298. [CrossRef] [PubMed] 
35. Blunk, E.M.; Williams, S.W. The Effects of Curriculum on Preschool Children's Perceptions of the Elderly. Educ. Gerontol. 1997, 23, 233-341. [CrossRef]

36. Fillmer, H.T. Children's Descriptions of and Attitudes Toward the Elderly. Educ. Gerontol. 1984, 10, 99-107. [CrossRef]

37. Haught, P.A.; Walls, R.T.; Laney, J.D.; Leavell, A.; Stuzen, S. Child and Adolescent Knowledge and Attitudes About Older Adults Across Time and States. Educ. Gerontol. 1999, 25, 501-517. [CrossRef]

38. Lichtenstein, M.J.; Pruski, L.A.; Marshall, C.E.; Blalock, C.L.; Lee, S.; Plaetke, R. Sentence Completion to Assess Children's Views About Aging. Gerontologist 2003, 43, 839-848. [CrossRef]

39. Lichtenstein, M.J.; Pruski, L.A.; Marshall, C.E.; Blalock, C.L.; Liu, Y.; Plaetke, R. Do Middle School Students Really Have Fixed Images of Elders? J. Gerontol. B Psychol. 2005, 60, S37-S47. [CrossRef] [PubMed]

40. Pries-Kümmel, E. Wie junge Menschen über das Alter denken. Sozial Extra 2006, 30, 42-45. [CrossRef]

41. Schmidt-Hertha, B.; Schramm, S.; Schnurr, S. Altersbilder von Kindern und Jugendlichen. In Individuelle und kulturelle Altersbilder: Expertisen zum Sechsten Altenbericht der Bundesregierung; Berner, F., Rossow, J., Schwitzer, K.-P., Eds.; VS Verlag für Sozialwissenschaften: Wiesbaden, Germany, 2012; pp. 71-108.

42. McConatha, J.T.; Schnell, F.; Volkwein, K.; Riley, L.; Leach, E. Attitudes toward Aging: A Comparative Analysis of Young Adults from the United States and Germany. Int. J. Aging Hum. Dev. 2003, 57, 203-215. [CrossRef]

43. Ehret, S. Echo der Generationen; Lit Verlag: Münster, Germany, 2016.

44. McGuire, S.L.; Klein, D.A.; Couper, D. Aging Education: A National Imperative. Educ. Gerontol. 2005, 31, 443-460. [CrossRef]

45. Baltes, M.M.; Carstensen, L.L. The Process of Successful Ageing. Ageing Soc. 1996, 16, 397-422. [CrossRef]

46. Havighurst, R.J. Successful Aging. Gerontologist 1961, 1, 8-13. [CrossRef]

47. Greenberg, J.; Schimel, J.; Martens, A. Ageism: Denying the Face of the Future. In Ageism: Stereotyping and Prejudice against Older Persons; Nelson, T.D., Ed.; MIT Press: Cambridge, MA, USA, 2002; pp. 27-48.

48. Langer, N. Changing Youngsters' Perceptions of Aging: Aging Education's Role. Educ. Gerontol. 1999, 25, 549-554. [CrossRef]

49. Friedman, B. The Integration of Pro-Active Aging Education into Existing Educational Curricula. J. Gerontol. Soc. Work 1997, 28, 103-110. [CrossRef]

50. Duit, R.; Gropengießer, H.; Kattmann, U.; Komorek, M.; Parchmann, I. The Model of Educational Reconstruction-A framework for improving teaching and learning science. In Science Education Research and Practice in Europe: Retrosspective and Prospecctive; Jorde, D., Dillon, J., Eds.; SensePublishers: Rotterdam, The Netherlands, 2012; pp. 13-37.

51. Levy, S.R. Toward Reducing Ageism: PEACE (Positive Education about Aging and Contact Experiences) Model. Gerontologist 2018, 58, 226-232. [CrossRef] [PubMed]

52. Barnett, M.D.; Adams, C.M. Ageism and aging anxiety among young adults: Relationships with contact, knowledge, fear of death, and optimism. Educ. Gerontol. 2018, 44, 693-700. [CrossRef]

53. Cottle, N.R.; Glover, R.J. Combating Ageism: Change in Student Knowledge and Attitudes Regarding Aging. Educ. Gerontol. 2007, 33, 501-512. [CrossRef]

54. O'Hanlon, A.M.; Camp, C.J.; Osofsky, H.J. Knowledge of and Attitudes Toward Aging in Young, Middle-aged, and Older College Students: A Comparison of Two Measures of Knowledge of Aging. Educ. Gerontol. 1993, 19, 753-766. [CrossRef]

55. Goriup, J.; Lahe, D. The Role of Education and Knowledge about Aging in Creating Young People's Attitudes to the Elderly. Acta Educationis Generalis 2018, 8, 63-75. [CrossRef]

56. Stuart-Hamilton, I.; Mahoney, B. The Effect of Aging Awareness Training on Knowledge of, and Attitudes Towards, Older Adults. Educ. Gerontol. 2003, 29, 251-260. [CrossRef]

57. Allan, L.J.; Johnson, J.A. Undergraduate Attitudes toward the Elderly: The Role of Knowledge, Contact and Aging Anxiety. Educ. Gerontol. 2008, 35, 1-14. [CrossRef]

58. O'Hanlon, A.M.; Brookover, B.C. Assessing Changes in Attitudes about Aging: Personal Reflections and a Standardized Measure. Educ. Gerontol. 2002, 28, 711-725. [CrossRef]

59. Klein Austrin, D.; Council, K.J.; McGuire, S.L. Education to Promote Positive Attitudes about Aging. Educ. Gerontol. 2005, 31, 591-601. [CrossRef] 
60. The Standing Conference of the Ministers of Education and Cultural Affairs (KMK). Bildungsstandards der Kultusministerkonferenz: Erläuterungen zur Konzeption und Entwicklung; Luchterhand: München, Germany, 2005.

61. Ginschel, F.; Schlüter, K. Analyse von Altersbildern in Schulbüchern der Primarstufe und Sekundarstufe I. In Alternde Gesellschaft im Wandel: Zur Gestaltung einer Gesellschaft des langen Lebens; Woopen, C., Janhsen, A., Mertz, M., Genske, A., Eds.; Springer: Berlin, Germany, 2020; pp. 101-115.

62. Information und Technik NRW (IT.NRW), Statistisches Landesamt. Allgemeinbildende Schulen in NordrheinWestfalen 2018; Information und Technik NRW: Düsseldorf, Germany, 2019.

63. Mayring, P. Qualitative Content Analysis. Forum Qual. Soc. Res. 2000, 1. [CrossRef]

64. Schreier, M. Qualitative Content Analysis in Practice; SAGE Publications: London, UK, 2012.

65. VERBI Software. MAXQDA 2018; VERBI Software: Berlin, Germany, 2017.

66. Mehnert, H.; Standi, E. Typ-2-Diabetes. In Kompendium der Praktischen Medizin; König, B., Reinhardt, D., Schuster, H.-P., Eds.; Springer: Berlin, Germany, 2000; pp. 255-273.

67. Mergenthaler, A.; Micheel, F.; Schneider, N.F. Altes Eisen oder mitten im Leben? Lebenslagen, Lebensereignisse und Lebenspläne älterer Menschen in Deutschland; Konrad-Adenauer-Stiftung: Berlin, Germany, 2020.

68. Spuling, S.M.; Cengia, A.; Wettstein, M. Funktionale und subjektive Gesundheit bei Frauen und Männern im Verlauf der zweiten Lebenshälfte. In Frauen und Männer in der Zweiten Lebenshälfte: Älterwerden im Sozialen Wandel; Vogel, C., Wettstein, M., Tesch-Römer, C., Eds.; Springer Fachmedien: Wiesbaden, Germany, 2019; pp. 35-52.

69. Rensing, L.; Rippe, V. Altern. Zelluläre und Molekulare Grundlagen, Körperliche Veränderungen und Erkrankungen, Therapieansätze; Springer Spektrum: Berlin/Heidelberg, Germany, 2014. [CrossRef]

70. Bulterijs, S.; Hull, R.S.; Björk, V.C.E.; Roy, A.G. It is time to classify biological aging as a disease. Front. Genet. 2015, 6. [CrossRef] [PubMed]

71. Smith, R. In search of "non-disease". BMJ 2002, 324, 883-885. [CrossRef]

72. Zhavoronkov, A.; Bhullar, B. Classifying aging as a disease in the context of ICD-11. Front. Genet. 2015, 6, 326. [CrossRef]

73. Olshansky, S.J.; Hayflick, L.; Carnes, B.A. Position Statement on Human Aging. J. Gerontol. A Biol. Sci. Med. Sci. 2002, 57, B292-B297. [CrossRef]

74. Statistisches Bundesamt (Destatis). Pflegestatistik. Pflege im Rahmen der Pflegeversicherung Deutschlandergebnisse 2017; Statistisches Bundesamt: Wiesbaden, Germany, 2018.

75. Aday, R.H.; Sims, C.R.; Evans, E. Youth's Attitudes Toward the Elderly: The Impact of Intergenerational Partners. J. Appl. Gerontol 1991, 10, 372-384. [CrossRef]

76. Carstensen, L.; Mason, S.E.; Caldwell, E.C. Children's Attitudes Toward the Elderly: An Intergenerational Technique for Change. Educ. Gerontol. 1982, 8, 291-301. [CrossRef]

77. Couper, D.P.; Sheehan, N.W.; Thomas, E.L. Attitude Toward Old People: The Impact of an Intergenerational Program. Educ. Gerontol. 1991, 17, 41-53. [CrossRef]

Publisher's Note: MDPI stays neutral with regard to jurisdictional claims in published maps and institutional affiliations.

(C) 2020 by the authors. Licensee MDPI, Basel, Switzerland. This article is an open access article distributed under the terms and conditions of the Creative Commons Attribution (CC BY) license (http://creativecommons.org/licenses/by/4.0/). 